\title{
CARING ECONOMICS LEARNING TO DEVELOP CARING ATTITUDE AMONG HIGH SCHOOL STUDENTS
}

\author{
Daru Wahyuni $^{1,2 *}$, Ery Tri Djatmika ${ }^{1}$, Sri Umi Mintarti Widjaya ${ }^{1}$, Hari Wahyono ${ }^{1}$ \\ ${ }^{1}$ Universitas Negeri Malang, Indonesia \\ ${ }^{2}$ Universitas Negeri Yogyakarta, Indonesia \\ *e-mail: daru_wahyuni@uny.ac.id
}

\begin{abstract}
Even though economics learning in Senior High Schools has been able to increase students' economic knowledge, their economic behavior is still far from being appropriate, whereas their concern for others, the environment, and even for themselves is lacking. The aims of this study were to apply caring economics learning (CEL) at senior high schools in Indonesia and to observe the internalization of caring economics attitude among the students through action research. It contained instructional package consisting of lesson plans, student worksheets, instructional materials, instructional media, and learning assessment in the form of situational judgment tests (SJTs). The CEL employed case method that was implemented in three learning activities. The data were obtained through observation, interviews, tests, and documentation. The study has revealed that the CEL was assessed by the observers as good and excellent. The success of caring attitude development on the students was reflected in the number of students showing caring attitudes, which increased from the first learning activity (52\%) to the last one (95\%). Based on the SJT-1, 55.56\% of students achieved high scores and $44.44 \%$ had moderate scores. Based on the SJT-2, the number of students with high scores increased significantly $(77.78 \%)$, while the number of students who had moderate scores decreased considerably $(22.22 \%)$.
\end{abstract}

\section{Keywords: caring economics, case method, altruism, design-based research (DBR).}

\section{PEMBELAJARAN CARING ECONOMICS UNTUK MENUMBUHKAN KEPEDULIAN EKONOMI PADA SISWA SEKOLAH MENENGAH ATAS}

\begin{abstract}
Abstrak: Pembelajaran mata pelajaran ekonomi di Sekolah Menengah Atas relatif telah mampu meningkatkan pengetahuan siswa mengenai materi ekonomi namun perilaku ekonomi mereka masih kurang sesuai dan kurang memiliki kepedulian terhadap orang lain, lingkungan, dan bahkan terhadap dirinya sendiri. Penelitian ini merupakan penelitian tindakan yang bertujuan untuk mengaplikasikan pembelajaran caring economics di Sekolah Menengah Atas dan untuk mengetahui penanaman sikap kepedulian ekonomi pada siswa. Perangkat pembelajaran terdiri atas skenario pembelajaran, bahan ajar, lembar kerja siswa, media pembelajaran, dan instrumen situational judgment tests (SJTs). Pembelajaran caring economics diaplikasikan dengan menggunakan metode kasus dalam tiga kali kegiatan pembelajaran. Data penelitian diperoleh melalui observasi, wawancara, tes, dan dokumentasi. Keterlaksanaan pembelajaran caring economics masuk dalam kategori baik dan sangat baik. Jumlah siswa yang menunjukkan sikap kepedulian ekonomi meningkat yaitu sebanyak 52\% pada kegiatan pembelajaran ke-1 dan mencapai $95 \%$ pada akhir kegiatan pembelajaran ke-3. Berdasarkan SJT-1 siswa yang memperoleh nilai tinggi mencapai 55,56\% dan nilai sedang mencapai $44,44 \%$ sedangkan berdasarkan SJT-2 siswa yang memperoleh nilai tinggi mencapai $77,78 \%$ dan nilai sedang mencapai $22,22 \%$.
\end{abstract}

Kata Kunci: caring economics, metode kasus, altruisme, design-based research (DBR).

\section{INTRODUCTION}

The basic competence of the economics learning is to develop economics knowledge, economic attitudes, and skills to wisely manage limited resources in production, consumption, and distribution activities. In practice however, its application could be different to some extent. It was reported that many business practices have violated moral economics. For example, shop owners sell expired, broken, and hazardous 
goods (Paratmanitya \& Aprilia, 2016), factories dump their wastes directly to rivers (Zammi, Rahmawati, \& Nirwana, 2018), consumers decide on harmful or not eco-friendly products (Waskito \& Harsono, 2012), investors offer fraudulent investments (Hastuti, 2020), and many others. The economic behaviors conflict to the moral economic values, that is, all parties who have economic interests have to maintain mutual tolerance (Mubyarto, 1989).

Degradation of caring behavior towards other people and environment have been observed among Indonesian youngsters. An incident on an electric train has gone viral when two young girls refused to give up priority seats to pregnant women and the elderly (Suratkabar. id, 2019). Two teenagers were caught redhanded dumping trash into the Cibeureum river (SorotIndonesia.com, 2018). Surprisingly, it was reported that many vandals were high school students (Hidayat, 2019). Even though they do not represent Indonesian youngsters at large, the behaviors are very worrying.

The growing irrational economic behavior and insensitivity among Indonesian high school students described above raises a question about the economics learning at schools. Swasono (2014) has explicated that the practice of economics learning at all education levels in Indonesia tends to base on the liberalism that carries the nature of individualism and selfinterest. Capitalism has dominated almost all economics books in Indonesia (Wahjoedi, 2015), including economics textbooks for high school students. They contain the teachings and materials of neoliberalism that are worthy of debate as they are irrelevant and illogical (Mubyarto \& Santosa, 2004). Moreover, Mubyarto, \& Santosa (2004) criticized that theoretical economics has been taught in Indonesia for many years mostly centering on the analysis of homo economicus which generally reflects, as Elahi (2015) claims, the presence of unbounded selfishness, unbounded willpower, and unbounded rationality in carrying out economic activities. Disman (2004) reported that the practice of economic education in Indonesia has been more oriented to the ways how to transfer capitalist concepts. Consequently, students tend to hold strong capitalist economic values, attitudes, and individualistic behaviors prioritizing selfinterests and behave materialistically. The economic education in Indonesia probably has failed to invest social, moral, and ethical values in the attitudes and economic behavior of students. The present study claims that there must be resilient efforts to realize economic education with the basis of social, moral, and ethical values that could develop not only economics knowledge but also caring economic attitudes and behavior.

Many studies on the economics learning have been conducted. However, most of them focus on the application of teaching methods such as STAD (student teams achievement division) model (Sinaga, 2016), project based learning method (Mulyani, 2014), and cooperative learning model (Longdong, 2020). The others observe the application of learning media such as mobile learning (Alhafidz \& Haryono, 2018) and multimedia (Susana \& Masruri, 2015). Few studies are action research with the objective of developing critical thinking (Surasa, Witjaksono, \& Utomo, 2017) and improving learning motivation and achievements (Saptono, Soetjipto, Wahjoedi, \& Wahyono, 2020). Even though many studies on economics learning have been conducted, little is known about economics learning that can develop students' caring economic attitudes. The present study is conducted to develop caring economics learning that fosters caring economic attitudes of Indonesian senior high school students. Indonesian youngsters are potential economic actors in the future and hence they need to be introduced to the concept of moral economic in the economics learning.

The present study implements caring economics learning (CEL) that discusses how economic actors could behave as caring human beings, namely rational homo economicus who care for their fellow human beings and the environment when carrying out economic activities. Care in this sense is underlain by altruism that prioritizes compassion and the interests of others (Witjaksono, 2016). The caring human beings in caring economics is associated with the existence of two parties in caring relationships between care givers and care receivers who have a relationship to care for one another (Boris, Noddings, Michel, \& Mahon, 2002), with the form of mutual respect, mutual trust, and mutual benefit (Singer \& Snower, 2015); all of which reflect altruism 
among economic actors in carrying out economic activities.

Caring economics roots in values, attitudes, and practices to build social relations among people and the environment. It explicates human beings' sustainable efforts to live, to maintain, and to improve the quality of life (Van Osch, 2013). The caring activities in the concept of caring economics constitute the ones aimed at maintaining, sustaining, and improving physical and social relationships in the long-term and they are indispensable for sustaining the existence of human beings (Jochimsen, 2003). In its point of view, human beings are not self-centered but rather they care for others and the environment. Caring economics could accommodate a paradigm shift from homo economicus to caring human beings. In other words, it is beyond capitalism that favors the market economy and socialism that denounces it (Eisler, 2017). It should be noted however that it does not mean to abandon the practice of capitalism and socialism as markets and central planning are still required, but rather the challenge articulated by Eisler (2017) requires the society to look into emerging concepts or practices that could complete both economic ideologies.

Caring economics might offer a new perspective in the economy as it could collectively and holistically settle economic, environmental and social complications and it looks at welfare differently (Witjaksono, 2016). In its standpoint, welfare has deeper meaning than just about income and wealth and society is considered prosperous when all members live in better life (Singer \& Snower, 2015). Caring in the concept of caring economics roots in altruism (Witjaksono, 2016), which is a voluntary act carried out by a person or group of people to help others without any rewards in return (Myers, 2010; Taylor, Peplau, \& Sears, 2009). Altruism is motivated by kindness (Taylor et al., 2009) and consideration to help others (Arifin, 2015; Baron \& Byrne, 2005; Myers, 2010). It is prosocial behavior to be beneficial to others and it is not for individual interests (Crisp \& Turner, 2007). Altruistic behavior can be manifested in loving others, helping others do their time of need, and making sure that others are appreciated (Arifin, 2015). Importantly, it is done mutually (Jaffe, 2002).
Altruism comprises several good traits such as cooperation, sharing, generousity, helpfulness, honesty, and consideration (Baron \& Byrne, 2005). Altruistic people would favor doing activities in groups. They often give and share with others in need. They would be happy to help others solve problems, to sooth sadness, and to ease physical and psychological burdens. They love charity and they are generous to others in need and they have a righteous heart. They do not cheat but prioritize the value of honesty. They are willing to think about how others' rights can be fulfilled. In the present research, caring in the concept of caring economics covers the aspects of altruism as discussed above.

The caring economics learning in the present study was conducted with a designbased research (DBR) approach. The approach integrates designs and scientific methods to produce useful products and theories that are effectively solve educational problems faced by individuals or groups (Easterday, Lewis, \& Gerber, 2014). Research with DBR approach broadly comprises four phases: identification and problem analysis, solution scheme, repetitive design test and improvement, and reflection to produce design principles and their implementation (Amiel \& Reeves, 2008).

Beckisheva, Gasparyan, \& Kovalenko (2015) suggested the use of case method is a learning method with a design or scenario to apply the concepts learned in the classroom to real life situations. It enables learners to promote greater level of cognitive abilities (Yale Poorvu Center for Teaching and Learning, 2019) and encourages them to engage in discussions about cases occurring in the real world (Queen's University's Center for Teaching and Learning, 2019). With the information that is both relevant or not, and both true and false, the cases require interpretation and appropriate solutions through discussions (Volpe, 2015), and hence case method could promote interactive student-centered learning. By looking for information on a case collectively, learners can learn to analyze and propose the most appropriate solution (Foran, 2002). Studies have reported that case method is very advantageous for economics learning as it could enable students to do analytical work and explain the relationship between events in a case (Popescu, 2014) and it could improve their 
academic performance in economics (Habasesa \& Hlalele, 2014). In addition, it provides opportunities for teachers to choose cases for classroom activities based on specific learning objectives (Austin, Brody, \& Packard, 2009).

As discussed previously, caring economics presents a new perspective in the economy that could develop good traits such as cooperation, sharing, generousity, helpfulness, honesty, and consideration in the economic activities. Nevertheles, little has been done to integrate such good traits in economics learning. The objectives of the present study were to implement caring economics learning and to develop caring economic attitudes of Indonesian senior high school students. Even though the economics learning undertaken by the high school students in the present study was relatively limited in its scope, it would foster the basic knowledge of rational economic behaviors along with caring attitudes. Moreover, as they would become economic actors in the near future, they have to develop the knowledge right away. Importantly, it would develop altruistic economics knowledge and attitudes.

\section{METHOD}

\section{Research Design}

The type of the present research was action research. To internalize caring economic attitudes in the research participants, the present study employed caring economics learning (CEL). The CEL was carried out in 3 learning activities. The present study was conducted at a senior high school in Bantul regency, Yogyakarta. The study chose the tenth grade of the natural sciences major class randomly among the other tenth grade classses in the school. The study involved 36 students, 2 economics teachers, and 3 independent observers.

Empirical data were collected by means of observation, interviews, documentation, and tests. Observations were carried out throughout the learning activities to obtain comprehensive data of the implementation of the CEL and the emergence of the students' caring attitudes. Interviews were conducted to observe the students' opinions about the CEL. Documentation was used to record the students' work, including discussion worksheets, caring economics concept maps, and the students' daily journals. Situational judgment tests were administered to scrutinize their caring economic attitudes.

\section{Research Instrument}

The observation sheets of the implementation of caring economics learning. The observation sheets of learning activities consisted of 20 assessment items: 6 items for opening, 11 items for main learning activities, and 3 items for closing. The scores of the implementation of the caring economics learning ranged from 0 to 100 . A situational judgment test (SJT) was designed to measure the knowledge, job skills, or social skills of test takers in a relevant role setting (Krumm, Lievens, Hüffmeier, Lipnevich, Bendels, \& Hertel, 2015). The present study developed two SJTs shown in Table 1 and Table 2.

Table 1. The Grid of SJT-1 for Topic Basic Economics Concepts

\begin{tabular}{lcc}
$\begin{array}{l}\text { The Observed Aspects of } \\
\text { Caring Economic Attitudes }\end{array}$ & $\begin{array}{c}\text { Test } \\
\text { Item }\end{array}$ & $\begin{array}{c}\text { Number } \\
\text { of Item }\end{array}$ \\
\hline Unbounded selfishness & 1 & 1 \\
Unbounded rationality & 2 & 1 \\
Unbounded willpower & 3 & 1 \\
Generosity & 4 & 1 \\
Sharing & 5 & 1 \\
Helping & 6 & 1 \\
Honesty & 7 & 1 \\
\hline Total & & 7 \\
\hline
\end{tabular}

Table 2. The Grid of SJT-2 for Topic Main Economic Activities

\begin{tabular}{lcc}
\hline $\begin{array}{l}\text { The Observed Aspects of } \\
\text { Caring Economic Attitudes }\end{array}$ & $\begin{array}{c}\text { Test } \\
\text { Item }\end{array}$ & $\begin{array}{c}\text { Number } \\
\text { of Item }\end{array}$ \\
\hline Cooperation & $1,2,3$ & 3 \\
Consideration to others' & $4,5,6$ & 3 \\
Helping & 7,8 & 2 \\
Honesty & 9 & 1 \\
Unbounded willpower & 10 & 1 \\
\hline Total & & 10 \\
\hline
\end{tabular}


Every item of the SJT had 4 alternative answers with the score ranging from 0 to 3 . The SJT-1 and SJT-2 were validated by 3 experts in the field through professional judgments. The reliability of the SJTs was calculated by Alpha coefficients. On the advice of the experts, to make the test easily understood by the students, the SJT-1 and SJT-2 were revised in regard to the social situations used as the background of the tests and the language of the tests. The reliability of the SJTs was above .7 (SJT-1= .719 and SJT-2 $=.713$ ) which indicated good criteria. The results of the situational judgment tests were analyzed quantitatively and the results of the discussion and the daily journals were analyzed qualitatively to observe the development of the students' caring economic attitudes.

\section{RESULTS AND DISCUSSION Results}

The topics of the caring economics learning (CEL) were Basic Economics Concepts and Main Economic Activities (Consumption, Production, and Distribution). The CEL was implemented in three learning activities. Each learning activity consisted of planning, acting, observing, and reflecting. The planning of each learning activity was carried out by the researchers in collaboration with the economics teachers. In this stage, we compiled instructional package that consisted of lesson plans, instructional materials, instructional media, and learning assessments for each of the learning topic. The learning package was assessed by the appointed experts. The following sections discuss the acting, observing, and reflecting in each learning activity.

Thelearningactivitiesconsistedofopening, main activities, and closing. The procedure of case method was applied in the main activities in which the students solved the cases provided in the learning. The three appointed observers assessed the implementation of the CEL. They made field notes about the implementation of the CEL in particular regarding the students' altruistic attitudes or behaviors emerging during the learning activities. Reflection was carried out when one learning activity was completed. The next sections discuss the learning activities of the CEL.

\section{Topic 1: Basic Economics Concepts}

The basic economics concepts discussed in the learning were scarcity, choice and economics, economic principles, homo economicus and homo socius, the caring human being paradigm in the view of caring economics, and the value of altruism as the foundation of care. The learning objectives of lesson 1 were to enable the students to understand that economics is a series of interconnected concepts that underlay economic behaviors and to explicate that rational economic behavior is based on not only economic principles but also altruistic motivation, that is, caring for others and the environment.

The opening was carried out by providing information about the learning objectives, the scopes of the learning materials, the learning methods, and the method of assessment. The teacher employed student-centered learning combined with question and answer so as to encourage the students to be able to provide examples of events in the community that associated with the basic economics concepts. Through the learning strategy, they discussed many cases of caring economics relating to the basic economics concepts. The main activity involved case method in which the students were divided into six groups each of which discussed and solved the problem of case 1.1 entitled "Jodi: kala ada secercah asa" (Jodi: when there is a hope). Then, one of the groups presented the results of the discussion. The teacher and the students closed the learning by concluding the contents of the learning and evaluating the learning outcomes based on the results of SJT1. The implementation of the CEL was assessed by the observers. The average score of the implementation of the CEL was 85.33 which indicated that the implementation of the CEL was good.

The observers recorded the internalization of the caring economic attitudes of the students during the learning activities. Table 3 shows the observers' notes about the students' major caring economic attitudes. Table 4 presents the scores of the internalized caring attitudes based on the SJT-1. It shows that most of the students showed high level of caring attitude. 
Table 3. The Observers' Notes about Emerging Caring Attitude throughout the CEL

\begin{tabular}{|c|c|c|c|}
\hline No. & Learning Session & Observers' Notes & $\begin{array}{l}\text { Emerging } \\
\text { Caring Attitude }\end{array}$ \\
\hline 1. & $\begin{array}{l}\text { Delivering the } \\
\text { course }\end{array}$ & $\begin{array}{l}\text { The teacher showed a picture of a man in the train station } \\
\text { putting his bag on the seat next to him meanwhile many } \\
\text { other passengers are standing because they do not get empty } \\
\text { seats. The students stated that the man was very selfish. } \\
\text { A student asked the reason why at the beginning of the } \\
\text { Covid-19 pandemic, masks were very expensive. The teacher } \\
\text { asked the other students to answer. A student stated that the } \\
\text { price of masks was indeed raised by the seller to make a big } \\
\text { profit because they were in high demand. The teacher asked } \\
\text { whether the other students agreed with the sellers. Most of } \\
\text { them disagreed and thought that the sellers were greedy. } \\
\text { The teacher asked the students for their opinions about } \\
\text { vehicles that emit excessive and dirty exhaust fumes. The } \\
\text { students answered that they were annoying because they } \\
\text { disturbed others and induced air pollution. }\end{array}$ & $\begin{array}{l}\text { Disagreement } \\
\text { with the attitude } \\
\text { of unbounded } \\
\text { selfishness } \\
\text { Disagreement } \\
\text { with the attitude } \\
\text { of unbounded } \\
\text { rationality }\end{array}$ \\
\hline 2. & Group assignments & $\begin{array}{l}\text { The students shared work while they were constructing a } \\
\text { mind map of caring economics. }\end{array}$ & Cooperation \\
\hline & & $\begin{array}{l}\text { The group that had completed the mind map helped the other } \\
\text { groups to understand the concept of caring economics. }\end{array}$ & Helpful \\
\hline & $\begin{array}{l}\text { Discussing the } \\
\text { results of problem } \\
\text { solving. Case title: } \\
\text { "Jodi: kala ada } \\
\text { secercah asa" (Jodi: } \\
\text { when there is a hope) }\end{array}$ & $\begin{array}{l}\text { 1. The students identified that Jodi and his family faced } \\
\text { scarcity of economic resources. } \\
\text { 2. All the groups did fund raising activities to help the poor } \\
\text { family, although the creativity to solve the problem was } \\
\text { still limited. }\end{array}$ & Generosity \\
\hline
\end{tabular}

Table 4. The Scores of Situational Judgment Test 1

\begin{tabular}{cllc}
\hline No. & Range of Score & The Level of Caring Attitude & Total Students (\%) \\
\hline 1. & $X \leq 14$ & High & 55.56 \\
2. & $7 \leq X<14$ & Average & 44.44 \\
3. & $7<X$ & Low & .00 \\
\hline
\end{tabular}

According to the observation, the number of students who showed caring attitudes throughout the learning activity 1 was $52 \%$ and those who got high score in the SJT-1 were $55.56 \%$.

Reflection was carried out at the end of the learning activity 1 . Several things were found, among others: (1) during problem-solving discussions almost half of the students had difficulties identifying the problem in the case at hand; (2) the student worksheets did not provide good information for them to conduct coherent and directed case-solving discussions; (3) all the groups discussed the same case consequently they finished the discussion quickly and the discussion was less interesting; (4) only certain students were active in the groups and very few students dared to express their opinions;
(5) not all group members received sufficient supervision from the teacher; and (6) the learning media were very interesting, but the supporting images were too small.

Based on the observers' assessment and the field notes of the learning activity 1 , the teachers did several measures to improve the CEL that would be applied in the learning activity 2, for example: (1) modifying the problem identification activity that was previously carried out individually to become group activities; (2) improving the quality of the student worksheets by providing more detailed information; (3) providing cases that required more discussions; and (4) organizing effective time for delivering the course and conducting group or classroom discussions. 


\section{Topic 2: Main Economic Activities}

The main economic activities discussed in the CEL were consumption, consumption according to caring economics, production, production according to caring economics, distribution, and distribution according to caring economics. The learning objectives of lesson 2 were to enable the students to analyze the main economic activities in consumption, production, and distribution and to assist them to explicate the main economic activities carried out by the community that need to base on the caring economics.

The opening activity was carried out by providing information about the learning objectives, the scope of the learning materials, the learning methods, and the method of assessment. In the main activity, the teacher employed student-centered learning combined with question and answer so as to encourage the students to be able to provide examples of events in the community that associated with the main economic activities. Cases solved in the second learning activity were case 2.1. "Makan sambil belajar atau belajar sambil makan?" (Eating while learning or learning while eating?), case 2.2. "Burung hantuku sayang burung hantuku malang" (My beloved poor owls), and case 2.3 "Kadaluarsa yang jadi perkara" (Problematizing the expired medicine). Groups 1 and 2 discussed and solved the problems of case 2.1. Groups 3 and 4 discussed and solved the problems of case 2.2, and groups 5 and 6 discussed and solved the problems of case 2.3. With the help of the revised student worksheets, the students followed the stages of the case method. One of the groups presented the results of the discussion and the other groups responded to the presentation. At the end of the meeting the teacher and the students closed the learning by concluding the contents of the learning and evaluating the learning outcomes using SJT-2.

Table 5. The Observers' Notes about Emerging Caring Attitude throughout the CEL

\begin{tabular}{lll}
\hline No.Learning Session & Observers' notes & $\begin{array}{l}\text { Emerging } \\
\text { Caring Attitude }\end{array}$ \\
\hline
\end{tabular}

1. Delivering course

2. The results of the problem solving of case 2.1. Makan sambil belajar atau belajar sambil makan? (Eating while learning or learning while eating?)

3. The results of the problem solving of case 2.2. Burung hantuku sayang burung hantuku malang (My beloved poor owls)

4. The results of the problem solving of case 2.3 Kadaluarsa yang jadi perkara (Problematizing the expired medicines) teenagers to keep good behavior.
Many workers drove private cars to go to work and they shared the cost of gasoline with the neighbors who took a lift. The students thought that the neighbors and the car owners had mutual benefit because they could share transportation costs. The teacher told the students about a canteen that provided free meals and assisted anyone who wanted to contribute free food via the canteen. The students stated that it was a praiseworthy action because it could ease the burden on others.

The teacher showed news on the newspaper that YLKI (Indonesian Consumers Foundation) was protesting against a food manufacturer selling food products of which contents did not match with the information in the packaging. The students stated that the food producers lied to customers.

The teacher showed pictures of street vendors that fill out the sidewalk. The students stated that the vendors did not think about the interests of others.

Caring Attitude consumption activities

Helps in consumption activities

Honesty in production

Consideration to the rights of others in distribution

1. The students identified a problem in case 2.1: the selfishness of Consideration teenagers who ignored the interests of others when they were to the rights at a restaurant. of others in

2. Group 1 proposed that an authorized officer had to reprimand consumption the teenagers.

3. Group 2 stated that the family had important roles to advise the

1. The students identified a problem in case 2.2: poachers' Disagreement indifference to the survival of protected animals. People were with the attitude greedy for prioritizing their own interests (assuming Owls of unbounded were the pests for their Swallow breeding business). selfishness

2 . The proposed solution from group 3 and 4 was similar, namely the need for law enforcement by the local authority.

The students identified a problem in case 2.3: a pharmacy owner Honesty in sold expired medicines. The pharmacy lied to the customers. distribution $i$ Group 5 proposed a solution: protesting the deceptive pharmacy activities through YLKI (Indonesian Consumers Foundation).

Group 6 proposed a solution: reporting the deceptive pharmacy to the pharmacist association. 
The implementation of the CEL was assessed by the observers. The average score of the implementation of the CEL in the learning activity 2 was 89.00 which indicated that the application of the CEL was good. The observers identified the internalization of caring economic attitude during the learning activities. Table 5 presents the observers' notes about the students' major caring attitudes.

Table 6 presents the scores of the internalized caring attitudes based on the SJT-2. The table shows that most of the students showed high level of caring attitude.

Tabel 6. The Scores of Situational Judgment Test 2

\begin{tabular}{llll}
\hline No. $\begin{array}{l}\text { Range of } \\
\text { Score }\end{array}$ & $\begin{array}{l}\text { The Level of } \\
\text { Caring Attitude }\end{array}$ & $\begin{array}{l}\text { Total } \\
\text { Students }\end{array}$ \\
\hline 1. $X \leq 15$ & High & 77.78 \\
2. $10 \leq X<15$ & Average & 22.22 \\
3. $10<X$ & Low & .00 \\
\hline
\end{tabular}

Reflection was also carried out at the end of learning activity two. Several things were found, among others: (1) in the problem-solving discussions, the identification of problems was done in the groups, whereas the collection of relevant information and proposed solutions were carried out individually therefore the group discussion proceeded smoothly and regularly; (2) the instructions of the student worksheets were very communicative so that they were easily filled out by the students; (3) the cases were numerous and varied and they made the classroom discussion more active and interesting; (4) more than $75 \%$ of the students were active in the group discussions and the classroom discussions; (5) as the implementation of the group discussion was more organized, the teacher's attention and guidance was evenly distributed to all groups; and (6) the learning media was very interesting and they could be easily accessed by the students.

\section{Reinforcement}

In the third learning activity, the teacher did not discuss a new topic, but she assigned each student to write a journal recording cases on daily basis and discussed them in the groups. One interesting case was chosen to become the topic of the classroom discussion. Table 7 presents the notes about the students' caring attitude emerged during the group discussion.

Table 7. The Summary of the Cases

\begin{tabular}{|c|c|c|c|}
\hline No. & $\begin{array}{l}\text { Name of } \\
\text { the Group }\end{array}$ & Presented Cases & Emerging Caring Attitude \\
\hline 1. & Group 1 & $\begin{array}{l}\text { "Cantelan Sembako" (Food Package Hook) case. } \\
\text { During the Covid-19 pandemic, a villager hung packages } \\
\text { of food stuffs such as rice, vegetables, sugar, etc. on } \\
\text { the fence of his house. The food packages were free for } \\
\text { anyone. It turned out that many other villagers came } \\
\text { to the man's house to add more free food packages for } \\
\text { people in need. }\end{array}$ & $\begin{array}{l}\text { The proposed altruistic value was } \\
\text { generosity. }\end{array}$ \\
\hline 2. & Group 2 & $\begin{array}{l}\text { "Tukik di Pantai Gua Cemara" (Baby turtle in Gua Cemara } \\
\text { Beach) case. A conservation organization arranged an } \\
\text { activity to release turtle hatchlings at Gua Cemara beach, } \\
\text { at Sanden, Bantul regency. Many community members } \\
\text { came to take part in the activity. }\end{array}$ & $\begin{array}{l}\text { The proposed altruistic value of } \\
\text { the activity was protecting the } \\
\text { environment so as to support } \\
\text { sustainable economy. Another } \\
\text { altruistic value of the case was that } \\
\text { people had to respect other creatures' } \\
\text { right to live in this earth peacefully. }\end{array}$ \\
\hline 3. & Group 3 & $\begin{array}{l}\text { "Pekerjaan Reseller" (Resellers) case. } \\
\text { A family member of a student became an online reseller } \\
\text { of frozen food with a fair profit share. }\end{array}$ & $\begin{array}{l}\text { The proposed altruistic value was } \\
\text { cooperation in distribution. }\end{array}$ \\
\hline 4. & Group 4 & $\begin{array}{l}\text { "Tertipu Barang On-Line" (Conned by Online Goods) } \\
\text { case. A student bought clothes via an online shop. It } \\
\text { turned out that he received clothes of a different quality. } \\
\text { The other students said that the incident should not } \\
\text { happen. }\end{array}$ & $\begin{array}{l}\text { The proposed altruistic value was } \\
\text { honesty in production. }\end{array}$ \\
\hline 5. & Group 5 & $\begin{array}{l}\text { "Menjenguk Tetangga yang Sakit" (Comforting Sick } \\
\text { Neighbors) case. In the neighborhood where the students } \\
\text { lived, residents had a habit of visiting neighbors who were } \\
\text { ill to show care. }\end{array}$ & $\begin{array}{l}\text { The proposed altruistic value was } \\
\text { sharing with others. }\end{array}$ \\
\hline 6. & Group 6 & $\begin{array}{l}\text { "Sambatan" (community service) case. Villagers helped } \\
\text { neighbors who were building or repairing their houses. }\end{array}$ & $\begin{array}{l}\text { The proposed altruistic value was } \\
\text { helping others. }\end{array}$ \\
\hline
\end{tabular}


The average score of the CEL at the third learning activity was 91.03 , which indicated that the implementation of the CEL was excellent. At the end of the third learning activity, almost all of the students $(95 \%)$ were able to express their opinions about the value of altruism that underlied the caring economic cases proposed by their classmates.

\section{Discussion}

The caring economics learning for senior high school students in this study had been developed by the researchers in collaboration with the researchers using a design-based research (DBR) approach. The finding supports the study by Darmawan, Soetjipto, Djatmika, \& Wahyono (2021) that developed an economicbased entrepreneurial learning. The study pointed out that DBR approach could promote entrepreneurial learning based on caring economics that prioritizes entrepreneurial spirit and the care for others and society. The result also supports Dolmans (2019) who asserts that DBR approach could be conducted in real environment as it is locally applicable and it is in line with Euler \& Collenberg (2018) who assert that DBR approach is an innovative solution for secondary school students to learn new or blurred problems in urban economy. The finding agrees with Hernwall \& Söderberg (2020) who point out that DBR approach supports the development of understanding of new concepts in contemporary schools.

Case method was applicable to the caring economics learning (CEL). It could impressively improve the students' communication, collaboration, and analytical skills through problem solving activities. Cases relevant for the CEL were relatively numerous, varied, and easily obtained, and hence the CEL was very interesting and dynamic. With the method, the number of students who were actively involved in the classroom discussion increased from the learning activity 1 to the learning activity 3 . Through the CEL, they were able to analyze various problems and to provide appropriate solutions to the problems in the provided cases. The finding is in line with Habasesa \& Hlalele (2014) who reported that case method could improve students' academic performance in economics learning. The finding also supports Popescu (2014) who reported that case method could enable students to do analytical work, explain, and find out solutions to presented cases. The result agrees with Austin et al. (2009) who pointed out that case method enables teachers to select various cases for different learning objectives.

Caring economics learning could introduce caring human beings; character that is opposite to that of homo economicus. Through the given cases in the learning activities and the SJT-1 and SJT-2, most of the students did not agree with the characters of homo economicus such as unbounded selfishness, unbounded willpower, and unbounded rationality. This critical finding means that the caring economics learning in the present study could provide a new way of thinking in economics learning.

Caring economics acknowledges that human beings tend to maximize their utility. However, economic decisions are influenced by psychological factors such as the care to others and environment. It is true that human beings, as homo economicus, always act rationally by comparing the sacrifices with the results obtained. However, in the point of view of behavioral economics, human beings have limited rationality. Gintis (2020) pointed out that economic actors are not basically egoistic and they tend to behave cooperatively with others, even with strangers. The study also found that economic actors are willing to cooperate with other people at personal expenses even though they do not receive personal gains from such actions.

Caring economics could accommodate a paradigm shift from homo economicus to caring human beings. In the point of view of caring economics, caring attitude will sustain the economic viability of the society in all circumstances: in good and bad time, in time of crisis and war, and even if the market collapses (Van Osch, 2013). One interesting result of the present study relating to this was the students' caring attitude in the case of "Cantelan Sembako" (Food Package Hook). The case illustrated that during the Covid-19 pandemic, villagers provided free food stuffs such as rice, vegetables, sugar, etc. for people in need. Through the case, the students could learn that people having caring attitude could maintain the economic viability of the society during the Covid-19 pandemic. Community members could resolve economic 
difficulties by helping one other. This supports Hedenigg's (2021) finding that cooperation based on trust and solidarity is a major factor in the running of a partnership-oriented economy during the Covid-19 pandemic.

During the CEL, the students have exhibited altruism in economic decisions. For example, in the case 1.1. "Jodi: kala ada secercah asa" (Jodi: when there is a hope), all of the students suggested fund raising to help Jodi's family facing economic difficulties. A similar result was displyed by the students' daily journals regarding the habit of comforting sick neighbors. The finding agrees with Witjaksono (2016) who asserts that the care in caring economics is underlain by altruism that prioritizes compassion and the interests of others.

The caring attitude internalized to the high school students through the CEL adopted aspects of altruism by Baron \& Byrne (2005), namely cooperation, sharing, helping, generosity, honesty and consideration to others' rights. The present study has found that not all of the aspects could be easily integrated into economic activities. The students could identify the most common ones in the daily economic activities such as honesty, consideration to others' rights, cooperation, and helping. This is in line with Singer \& Snower (2015) who affirm that the four aspects are more obvious since they describe mutually beneficial relationships between the perpetrators. Singer \& Snower (2015) stated that sharing and generosity occur the least often in economic activity. This could be because the two aspects have more to do with personal feelings that cannot be observed directly by others. However, the students were able to identify some facts reflecting the two aspects even though they were not included in the economic activities (production, consumption, or distribution).

Doing a job based on an altruistic attitude produces pleasant feelings for the perpetrators. Based on the interviews, many students stated that during the CEL they felt that they had practiced a caring attitude towards the economy, namely when they worked together and helped each other to complete group works (reflection of a production activity in its simple scope). After completing the activities, the students felt very happy and satisfied with the results achieved together. The results are in line with the research by $\mathrm{Hu}, \mathrm{Li}, \mathrm{Jia}, \& \mathrm{Xie}$ (2016) that explored altruistic behavior of people in the society. The research reported that people who provide assistance to others have warmer feelings towards their surroundings than those who do not. Thus, altruistic actors could benefit from their altruistic actions. Altruistic attitude needs to be developed continuously through caring economics learning so that Indonesian students can obtain good benefits from cultivating altruistic attitudes. Furthermore, through the CEL, sharpening students' sensitivity to social problems could be achieved by providing information, photos, news, and videos about the acts of caring and indifference in the community.

The success of internalizing caring attitudes, apart from being observed throughout the implementation of the CEL, was observed in the results of the situational judgment tests conducted at the end of the first learning activity and the second learning activity. The present study found the increase in the number of students who had a high level of caring attitude and the decrease in the number of students who had a low to moderate level of caring attitude. The results of the CEL indicated that caring attitudes could be developed through economics learning and the CEL could be applied to economics learning in other classes and schools. CEL with various learning models should be explored by future researchers so that it would be more interesting. Importantly, moral economics concept should be incorporated in the curriculum of economics learning in Indonesia.

\section{CONCLUSION}

The caring economics learning was conducted to develop the caring attitude of Indonesian senior high school students. Efforts to foster caring attitudes were carried out using case method. The cases presented in the CEL were the ones related to the inconsiderate economic actors who conducted economic activities. By discussing the cases, the students could improve their awareness of economic caring.

Case method is an effective learning instruction for caring economics learning as it enables students to improve their analytical, communication and collaboration skills through problem solving. With perpetual direction and encouragement, they get used to observe and analyze various social and economic problems. Through problem solving activities, they can 
improve their sensitivity and consideration towards others and the environment. CEL with case method can be applied to teach all topics of economics. However, teachers should choose cases that are suitable with the topic of discussion.

\section{ACKNOWLEDGEMENTS}

I would like to thank the Directorate General of Higher Education, Ministry of National Education, Indonesia that has provided scholarship to support this research.

\section{REFERENCES}

Alhafidz, M. R. L., \& Haryono, A. (2018). Pengembangan mobile learning berbasis android sebagai media pembelajaran ekonomi. [Development of android-based mobile learning as an economics learning media]. Jurnal Pendidikan Ekonomi, 11(2), 118-135 http://journal2.um.ac.id/ index.php/jpe/article/view/3450.

Amiel, T., \& Reeves, T. C. (2008). Design-based research and educational technology: Rethinking technology and the research agenda. Educational Technology and Society, 11(4), 29-40. http://www.jstor. org/stable/jeductechsoci.11.4.29.

Arifin, B. S. (2015). Psikologi sosial [Social psychology]. Bandung, Indonesia: Pustaka Setia.

Austin, M. J., Brody, R., \& Packard, T. (2009). Managing the challenges in human service organizations: A casebook. Thousand Oaks, CA: SAGE Publications. http:// dx.doi.org/10.4135/9781452274805.

Baron, R. A., \& Byrne, D. (2005). Social psychology. (R. Djuwita, Trans). Jakarta, Indonesia: Erlangga. (Original work published 2003).

Beckisheva, T. G., Gasparyan, G. A., \& Kovalenko, N. A. (2015). Case study as an active method of teaching business English. Procedia - Social and Behavioral Sciences, 166, 292-295. http://doi. org/10.1016/j.sbspro.2014.12.526.

Boris, E., Noddings, N., Michel, S., \& Mahon, R. (2002). No place like home? Starting at home: caring and social policy child care policy at the crossroads: gender and welfare state restructuring. The Women's Review of Books, 20(1), 21-22. http://doi. org/10.2307/4024019.

Crisp, R. J., \& Turner, R. N. (2007). Essential social psychology. London: Sage Publication.

Darmawan, I., Soetjipto, E. B., Djatmika, E. T., \& Wahyono, H. (2021). The development of the entrepreneurship learning design based on caring economics to enhance spirit of entrepreneurship and entrepreneurial intentions. Humanities and Social Sciences Letters, 9(1), 1-13. https://doi. org/10.18488/journal.73.2021.91.1.13.

Disman, D. (2004). Efektivitas pendidikan ekonomi dalam pembentukan nilai-nilai perilaku ekonomi kekeluargaan siswa SMA negeri di Kota Bandung. [The effectiveness of economic education in the formation of the values of family economic behavior for public high school students in Bandung City]. (Doctoral Dissertation, Universitas Pendidikan Indonesia). http://repository.upi.edu/id/ eprint/7894.

Dolmans, D. H. J. M. (2019). How theory and design-based research can mature PBL practice and research. Advances in Health Sciences Education, 24, 879-891. http:// doi.org/10.1007/s10459-019-09940-2.

Easterday, M. W., Lewis, D. R., \& Gerber, E. M. (2014, 23-27 June). Design-based research process: Problems, phases, and applications. Paper presented at $11^{\text {th }}$ International Conference of the Learning Sciences: Learning and Becoming in Practice, ICLS 2014 - Boulder, United States.

Eisler, R. (2017). Roadmap to a caring economics: Beyond capitalism and socialism. Interdisciplinary Journal of Partnership Studies, 4(1), 1-24. http:// doi.org/10.24926/ijps.v4i1.149.

Elahi, K. Q. -I. (2015). Homo economicus in neoclassical economics: Some 
conceptual curiosities about behavioural criticisms. Homo Oeconomicus, 32(1), 23-51. https://www.econbiz.de/Record/ homo-economicus-in-neoclassicaleconomics-some-conceptual-curiositiesabout-behavioural-criticisms-qudratelahi-khandakar/10011299163.

Euler, D., \& Collenberg, M. (2018). Designbased research in economic education. Educational Design Research, 2(1), 1-15. https://doi.org/10.15460/eder.2.2.1271.

Foran, B. J. (2002). The case method and the interactive classroom. The NEA Education Journal, 17(1), 41-50. https:// www.academia.edu/1277260/The case method and the interactive classroom.

Gintis, H. (2020). Beyond homo economicus: Evidence from experimental economics. Ecological Economics, 35(3), 311322. http://doi.org/10.1016/s0921$\underline{8009(00) 00216-0 .}$.

Hastuti, R. K. (2020, 3 July). OJK kembali temukan 99 investasi bodong, nih daftarnya! CNBCindonesia https://www.cnbcindonesia.com/ tech/20200703133332-37-170000/ojkkembali-temukan-99-investasi-bodongnih-daftarnya.

Hedenigg, S. (2021). Caring economics, cooperation, and the COVID-19 Pandemic. Interdisciplinary Journal of Partnership Studies, 8(1), 1-32. https:// doi.org/10.24926/ijps.v8i1.3681.

Hernwall, P., \& Söderberg, I. -L. (2020). Teaching about personal finance in HCS Suggestions from a design-based research approach. Designs for Learning, 12(1), 29-44. http://doi.org/10.16993/dfl.142.

Hidayat, T. A. (2018, 30 January). Pelaku vandalisme umumnya remaja. JabarEkspes.com. http://jabarekspres. com/2018/pelaku-vandalisme-umumnyaremaja.

Hu, T. -Y, Li, J., Jia, H., \& Xie, X. (2016). Helping others, warming yourself: Altruistic behaviors increase warmth feelings of the ambient environment. Frontiers in Psychology, 7(1349), 1-12, http://doi.org/10.3389/fpsyg.2016.01349.

Jaffe, K. (2002). An economic analysis of altruism: Who benefits from altruistic acts? Journal of Artificial Societies and Social Simulation, 5(3), 1-12. http://jasss. soc.surrey.ac.uk/5/3/3.html.

Jochimsen, M. A. (Ed.). (2003). Careful economics: Integrating caring activities and economic science. Boston, MA: Springer. http://doi.org/10.1007/978-14757-4714-0.

Krumm, S., Lievens, F., Hüffmeier, J., Lipnevich, A. A., Bendels, H., \& Hertel, G. (2015). How "situational" is judgment in situational judgment test? Journal of Applied Psychology, 100(2), 399-461. https://doi.org/10.1037/a0037674.

Longdong, M. (2020). Penerapan model pembelajaran kooperatif number head together sebagai upaya peningkatan hasil belajar ekonomi siswa kelas X IPS SMA Negeri 2 Manado. [Application of the number head together cooperative learning model as an effort to improve the economic learning outcomes of class $\mathrm{X}$ IPS students at SMA Negeri 2 Manado]. Dinamika Pembelajaran, 2(3), 72-78. http://ejournal.unima.ac.id/index.php/ dilan/article/view/2350.

Mubyarto, M. (1989). Ekonomi moral [Moral economics]. Journal of Indonesian Economy and Business, 4(1), 1-11. https://jurnal.ugm.ac.id/jieb/article/ view/40730/22750.

Mubyarto, M., \& Santosa, A. 2004. Pendidikan ekonomi alternatif di sekolah-sekolah lanjutan. [The Alternative economics education in secondary schools]. Paper presented at Seminar Bulanan ke 13 Pusat Studi Ekonomi Pancasila, Univeritas Gajah Mada, Indonesia.

Mulyani, E. (2014). Pengembangan model pembelajaran berbasis projek pendidikan kewirausahaan untuk meningkatkan sikap, minat, perilaku wirausaha, dan prestasi 
belajar siswa SMK. [Development of learning models based on entrepreneurship education projects to improve attitudes, interests, entrepreneurial behavior, and learning achievement of vocational high school students]. Cakrawala Pendidikan, 33(1), 50-61. https://doi.org/10.21831/ cp.v1i1.1861.

Myers, D. G. (2010). Social psychology (10 ed). New York, NY: McGraw Hill.

Paratmanitya, Y., \& Aprilia, V. (2016). Kandungan bahan tambahan pangan berbahaya pada makanan jajanan anak sekolah dasar di Kabupaten Bantul. [The content of dangerous food additives in snacks for elementary school children in Bantul Regency]. Jurnal Gizi dan Dietetik Indonesia (Indonesian Journal of Nutrition and Dietetics), 4(1), 49-55. http://dx.doi. org/10.21927/ijnd.2016.4(1).49-55.

Queen's University's Center for Teaching and Learning. $\quad$ http://www.queensu.ca/ctl/ what-we-do/teaching-and-assessmentstrategies/case-based-learning.

Saptono, L., Soetjipto, B. E., Wahjoedi, W., \& Wahyono, H. (2020). Role-playing model: Is it effective to improve students' accounting learning motivation and learning achievements? Cakrawala Pendidikan, 39(1), 133-143. http://doi. org/10.21831/cp.v39i1.24781.

Sinaga, D. (2016). Penerapan model student teams achievement division untuk meningkatkan hasil belajar dan kreativitas belajar ekonomi. [The application of the student team achievement division model to improve learning outcomes and economic learning creativity]. Cakrawala Pendidikan, 35(3), 357-364. http://doi. org/10.21831/cp.v35i3.10518.

Singer, T., \& Snower, D. J. (2015, 8-11 April). Caring economics. Paper presented at Annual Conference of the Institute for New Economic Thinking, Paris. https:// www.ineteconomics.org/research/ research-papers/caring-economics.
SorotIndonesia.com. (2018, 27 September). Satgas citarum kembali pergoki warga buang sampah sembarangan di Sungai Cibeureum. Sorotindonesia.com. http:// sorotindonesia.com/satgas-citarumkembali-pergoki-warga-buang-sampahsembarangan-di-sungai-cibeureum.

Surasa, N. N., Witjaksono, M., \& Utomo, S. H. (2017). Proses belajar siswa dalam meningkatkan kemampuan berpikir kritis mata pelajaran ekonomi SMA. [Learning processes in economics subject for improving high school students critical thinking]. Jurnal Pendidikan: Teori, Penelitian, dan Pengembangan, 2(1), 72-84. http://journal.um.ac.id/index.php/ jptpp/article/view/8443.

Suratkabar.id. https://www.suratkabar.id/90319/ peristiwa/miris-ditegur-ibu-hamil-karenaduduk-di-kursi-prioritas-jawaban-2remaja-ini-bikin-sentimen.

Susana, F. E., \& Masruri, M. S. (2015). Pengembangan multimedia pembelajaran ekonomi SMA/MA dengan materi permintaan dan penawaran. [Developing economics multimedia for the grade students of senior high school/islamic high school for teaching supply and demand]. Jurnal Inovasi Teknologi Pendidikan, 2(1), 64-73. https://doi.org/10.21831/ tp.v2i1.5204.

Swasono, S. E. (2014). Indonesia dan doktrin kesejahteraan sosial dari klasik dan neoklasik sampai the end of laissez faire. [Indonesia and the Doctrine of Social Welfare from Classical and Neoclassical to the End of Laissez Faire]. Jakarta, Indonesia: Pra Karsa.

Taylor, S. E., Peplau, L. A., \& Sears, D. O. (2006). Social psychology. New Jersey, NJ: Pearson.

Van Osch, T. (2013). Towards a caring economics approach. https://oqconsulting.eu/wpcontent/uploads/2020/04/The-Economyof-Care.pdf. 
Volpe, G. (2015). Case teaching in economics: History, practice and evidence. Cogent Economics and Finance, 3(1), 1-18. http://doi.org/10.1080/23322039.2015.11 20977.

Wahjoedi, W. (2015). Pendidikan ekonomi berkarakter nilai-nilai Pancasila. [Economics education characterized by Pancasila values]. Malang, Indonesia: Universitas Negeri Malang.

Waskito, J., \& Harsono, M. (2012). Green consumer: Deskripsi tingkat kesadaran dan kepedulian masyarakat Joglosemar terhadap kelestarian lingkungan. [Green consumer: A description of the level of awareness and concern of the people of Joglosemar towards environmental sustainability]. Jurnal Dinamika Manajemen, 3(1), 29-39. https://journal. unnes.ac.id/nju/index.php/jdm/article/ view/2457.
Witjaksono, M. (2016). Analisis kritis dan pragmatis caring economics sebagai paradigma baru kajian ekonomi. [Critical and pragmatic analysis of caring economics as a new paradigm of economic studies]. Jurnal Ekonomi dan Ekonomi Studi Pembangunan, 8(2), 217-244. $\quad$ http://dx.doi.org/10.17977/ um002v8i22016p217.

Yale Poorvu Center for Teaching and Learning (n.d.). Case-based learning. https://ctl. yale.edu/faculty-resources/strategiesteaching/case-based-learning.

Zammi, M., Rahmawati, A., \& Nirwana, R. R. (2018). Analisis dampak limbah buangan limbah pabrik batik di Sungai Simbangkulon Kabupaten Pekalongan. [Analysis of the impact of waste from the batik factory in the Simbangkulon River, Pekalongan Regency]. Walisongo Journal of Chemistry, 1(1), 1-5. https:// doi.org/10.21580/wjc.v2i1.2667. 